\title{
World War II in Soviet Prose - An Overview
}

\section{OLGA GRĂDINARU*}

\begin{abstract}
The main focus of our study is the representation of World War II in the Soviet literature from the war period to the '90s. Several literary works are analysed as representative for the historical, political and cultural background due to their main themes, narrative structure and character construction. The main concepts used in our analysis pertain to the Russian cultural context, on the one hand - heroism, heroic and heroic deed - and to Socialist Realism, on the other - positive hero. We distinguish four main perspectives in the war depiction: romantic-heroic, psychological, philosophical and authentic.
\end{abstract}

Keywords Great Patriotic War, Socialist Realism, war prose, heroization, demystification.

World War II has been playing a significant role in the Soviet and post-Soviet context. It represented a binder with the Patriotic War of 1812 since it had a legitimate selfdefence nature for the Soviet citizens. Therefore, it is known as the "Great Patriotic War" / Velikaia Otechestvennaia Voina, mobilizing all the Soviet mythmaking capacity and previous heroic resources to describe it. In view of the Socialist Realism canon, Soviet literature had to reflect the war in a conflicting manner, taking into account "what is" and "what ought to be. ${ }^{1 "}$ Given the Russian cultural background imbued with heroism since The Song of Igor's Campaign of the $12^{\text {th }}$ century, ${ }^{2}$ on the one hand, and the Soviet tendency of heroicising the daily deed, on the other, the

\footnotetext{
* Babeş-Bolyai University, Cluj-Napoca. olgagradinaru@gmail.com.

DOI: 10.26424/philobib.2021.26.2.07

The research for this article was sponsored by the Romanian Young Academy, which is funded by Stiftung Mercator and the Alexander von Humboldt Foundation for the period 2021-2023.

${ }^{1}$ Katerina Clark, The Soviet Novel: History as Ritual, third edition (Indiana University Press, Bloomington and Indianopolis, 2000), 36-37.

2 See more details in Olga Grădinaru, Războiul sovietic între idealizare și demitizare (ClujNapoca: Casa Cărții de Știință, 2018), 32-35.
} 
abundance of literary works that followed is not surprising. However, the variety of styles, perspectives and tendencies in war depiction is astonishing, linked to political and cultural changes.

The starting point of our research is the special status of the Soviet literature, corresponding, in Katerina Clark's opinion, to popular literature. Moreover, the resemblance of Socialist Realism cultural productions to fairy tales and medieval texts requires an eclectic approach, involving historical, anthropological and literary theory methods. While specific Soviet novels and stories represented the focus of literary critics, there is a virtual lack of cohesive and comprehensive approaches on the literary phenomenon generated by World War II. Our aim is to offer a dynamic overview of the Soviet war prose, taking into account the evolution of political, social and cultural factors since the war period to the ' $90 \mathrm{~s}$.

Socialist Realism, the impeccable example of fusion between political ideas and literary forms, encouraged the inspiration from real cases, recommending the adjustment of the positive hero according to the Soviet socialist standards. Elena Senyavskaya points out the process: taking an already formed popular hero/heroine, transforming him/her into a symbol to serve propagandistic purposes. A true phenomenon of 'mass copying' of literary heroes and heroines inspired by real life developed, resembling the mass edition of example of heroic deed. ${ }^{3}$ In that way the function of generating myths of an ideological-communist character was fuelled by the ideological-didactic role of literature. This process of transforming historical events into symbols is not new in Russia, but the communist rule raised this phenomenon to a different level. In this way, we assist at a controlled manner to reaffirm social examples of heroism in the conscience of the people in order to instil a sui-generis mentality of the so-called new born 'Soviet people'.

The working method consists in analysing the representative literary creation of a period and synthesizing the general perspective on the war representation. While the method may reduce the nuances, it crystalizes the essence of a literary tendency in a given period. We limited our research to novels and stories that had a great impact in the era and influenced other writings. Thus, the romantic-heroic perspective is best represented by Alexander Fadeyev's novel The Young Guard (1945, 1951), taking into account the romantic, idealized and heroicised perspective on war events. The novel The Russian Forest (1953), written by Leonid Leonov, opened the philosophical perspective in the Soviet war prose. Yuri Bondarev's The Hot Snow (1970) stands for an entire generation of war writers, former soldiers and lieutenants, preoccupied with the "truth of the trenches" and soldier's perceptions instead of the embellished/ heroicised view on war events. This is the psychological perspective, which started with the second wave of war writers, reflecting the "Thaw" waves of the post-Stalinist period. The authentic perspective

${ }^{3}$ Elena Senyavskaya, Psikhologia voiny v XX veke: istoricheskii opyt Rossii (Moscow, 1999). 
on World War II events is brought by writings of oral history of the '80s - Ales Adamovich, Daniil Granin, Yanka Bryl and Uladzimir Kalesnik, followed by Svetlana Alexievich. Although the last perspective does not comprise fiction, it is telling that the war horrors and tragedies do not need a narrator, fictional setting and are told in a raw, naturalistic manner. Moreover, Svetlana Alexievich's type of writing is situated at the verge of fiction and document, or, in her own words, "a choir of alive voices." In this respect, Svetlana Alexievich's first book - The Unwomanly Face of War (1985) - is both a manifesto against the accepted and acceptable war narratives in the Soviet milieu and a female statement in a predominantly male narrative.

Before proceeding to the prose analysis, two main aspects must be stated. Our analysis does not take into account the previous Russian war prose and the prose of World War I and the Russian Civil War, regardless of the historical period. ${ }^{4}$ The second aspect is that the war prose is dynamic and heterogeneous and each of the underlined perspectives does not necessarily exclude the existence of others. The variety of tones, perspectives of the post-Soviet prose dedicated to the Great Patriotic War stands as proof in this regard.

\section{Alexander Fadeyev and Ideological Fictionalization}

Alexander Fadeyev adopted a heroic-romantic perspective on war events in his novel inspired by the resistance movement in Krasnodon. Given the fact that the book was a party order and it was rewritten according to clear instructions, The Young Guard is a classic case of ideological fictionalization (that is to a higher degree than an average Socialist Realism book). This was in line with the heroic tone of Fadeyev's previous writings imbued with Bolshevik and socialist convictions, but also adding lyrical-romantic ingredients. Considered by M. Gorky the loyal exponent of Socialist Realism, Fadeyev considered that "Socialist realism was not a dogma of creativity, ${ }^{5 \text { " }}$ but a "profound conception of life, the result of Soviet artists' work with various individualities and distinctive creativity. ${ }^{6 "}$ This "profound conception of life" cost Fadeyev the rewriting of the novel The Young Guard, according to Stalin's specific requirements and under the close watch of Andrei Zhdanov who also supervised the (re)making of some scenes from Sergey Gerasimov's film adaptation (1948).

The first edition of Alexander Fadeyev's novel was written in a year and nine months; the novel was published in Komsomol 'skaya Pravda and Znamya in 1945, and a year later followed the book. It was not until December 1947 that some flaws of Fadeyev's novel were pointed out in an article in Pravda - "the main flaw of the

\footnotetext{
${ }^{4}$ See more about the revolutionary perspective in Grădinaru, 51-62.

${ }^{5}$ S. Rybak, "Pisatel'-boets" in A. Fadeev, Molodaya gvardia (Chişinău: Literatura artistică, 1977), 650.

6 Ibid., 651.
} 
novel is the incomplete and even representation of the party ruling involved in the heroic fight of komsomolists in Krasnodon," which resulted in the "wrong presentation of the role of the party in represented events and the real leaders of this fight. ${ }^{8 "}$ Another reproached aspect to the author was that "Fadeyev didn't create typical characters of communist-educators. ${ }^{9 \prime}$ While the first edition of the novel had 54 chapters, the second one had 65 , mainly concerned with the portraits and activity of the party leaders involved in the anti-fascist resistance.

The motif of "party man's capacity to act under life-threatening circumstances" is fructified in the novel The Young Guard with great literary mastery. However, it is achieved with a higher dose of lyrical-patriotic notes than in the novel The Rout (1927), considered by Soviet critics a masterpiece (along with Chapayev (1923) by Dmitry Furmanov and The Iron Flood (1924) by Alexander Serafimovich). The same manner of representation is specific to both novels, but The Young Guard presents the interior changes of Soviet youth from a lyrical-romantic perspective in difficult times for Soviet territories under fascist occupation.

The construction of characters in The Rout - Levinson and Morozka - were based on the successful ingredient of the positive character: self-education and overcoming personal weaknesses, aspects also used in the construction of Ulyana Gromova, Oleg Koshevoy, Sergey Tyulenin, Lyuba Shevtsova, the young fighters of Krasnodon from The Young Guard. The Soviet critics mentioned the fact that "Fadeyev's style of creation, the profoundness of psychological characterization of literary heroes, the attention to the interior universe are the proof of creative inheritance of L. Tolstoy's realistic writing, a fact confirmed many times by A. Fadeyev himself. ${ }^{10 \prime}$ Gorky's influence is to be seen in the so-called spiritual growth of the people and the development of the socialist conscience of the heroes. Thus, The Young Guard is the novel of an authentic spiritual-socialist revival of young people at war. That is a novel depicting the special role of every member of the antifascist organization after awakening the socialist conscience, as well as their role and identity in those harsh times.

The lyricism of the novel is partly due to the author's enthusiasm finding out about the heroism of young people of Krasnodon, a multiplied enthusiasm in many cities of the Soviet state due to the propaganda and myth-making machine. This enthusiastic impression of the writer is crucial for the tone of the proletarian literature, as it was stated many times by Fadeyev on many occasions. ${ }^{11}$

\footnotetext{
7 "Molodaya gvardia v romane i na stsene" in Pravda, December 3, 1947.

8 "Molodaya gvardia v romane i na stsene."

9 A. Bushmin, Aleksandr Fadeyev. Cherty tvorcheskoi individual'nosti. Izdanie vtoroe, dopolnennoe (Leningrad: Khudozhestvennaya literatura 1983), 183.

10 Ibid., 668.

11 R. Cockrell, "Aleksandr Fadeyev as Literary Theorist (1927-1932)" in Slavic East European Review, vol. 64, no. 3, July $1986 . . ., 345-346$.
} 
The novel follows the chronological order of events, fact that confers the status of war chronicle and creative act. The documentary nature of the novel is a specific trait of the Soviet war prose. Despite several styles and genres during the Second World War and afterwards, there are some other literary works of the same period and with the same stylistic features: The Taking of Velikoshumsk (1944) by Leonid Leonov and several chapters of Mikhail Sholokhov's They Fought for Their Country (1942). These writings contribute to the crystallization of a new direction within the Soviet literature marked by overcoming the chronicle-like representation of the Second World War to a more profound unveiling of war.

According to the ideological requirements of those times, the novel The Young Guard was considered a "heroic poem about the heroic greatness of the people" and a "heroic epic about the people's struggle for freedom ${ }^{12 "}$ as well as a "poem of the great deed of the Soviet young generation. ${ }^{13 "}$ We may talk about the mass heroism of the new generation, educated in the spirit of socialism and conducted into anti-fascist battle by the examples of parents during revolutionary years. ${ }^{14}$ The sacrifice of young fighters is valuable, especially considering the Soviet perspective on war events: the attack of imperialists on the newly established socialist state. These aspects must have contributed to the decision to include the novel in Soviet curriculum, being suitable for didactic-propagandistic aim of the party. It is significant that the novel was the second most published novel in the category of literature for children and teenagers in the Soviet Union during the period 1917-1987 - 276 editions and 26.143.000 million copies. ${ }^{15}$

During the rewriting process of the novel, the fictional facts were corrected according to the ideological requirements of the party. As a result, the novel became the canon version of events and a valuable item in the Soviet myth-making process. Fadeyev stated that he "didn't want to offer the history of 'The Young Guard', but to depict the Soviet man under occupation from the youth perspective, to offer the perspective of the entire society, including the youth as the future of this society and the primal indicator of its indubitable triumph. ${ }^{16 "}$

While auctorial independence was a matter of the past during Stalinist era, Fadeyev had to accept the directive to confer profundity to the subject of the novel.

\footnotetext{
12 Bushmin, 188-189.

${ }^{13}$ V. Şoptereanu, Istoria literaturii sovietice ruse: receptarea ei în România (Bucharest: Editura Universității, 1987), 141.

14 Lyuba Shevtsova wanted to be Chapayev, Oleg Koshevoy chose the nick-name of Kashuk, the name of his stepfather that fought in the Ukrainian civil war. Sergey Tyulenin regretted the fact that he wasn't born in the period of his heroes - Mikhail Frunze, Klim Voroshilov, Sergo Ordzhonikidze, Sergey Kirov.

${ }^{15}$ E. L. Nemirovski, M. L. Platova, Knigoizdanie SSSR. Tsifry i fakty. 1917-1987 (Moscow: Kniga, 1987).

16 Rybak, 665.
} 
And that meant representing the idea of legitimation of the new generation through the literary motive of passing the baton - the obsession of the Stalinist times in the political and cultural areas. While in the first edition of the novel the main characters are adventurous and full of initiative teenagers, heroes of a partly clumsy and childish resistance, the second edition introduces the previously approved figures of the older generation to have fought the new fascist order in the Ukrainian town. This elder generation also prepared and lead the young generation into (greater than real) actions against the Germans. The new edition of the novel has two points of interest: the Bolshevik leaders with the experience of the Civil War and Revolution, the brains of the operations and the young restless and patriotic inhabitants of Krasnodon in action. We may even talk about the appearance ex nihilo of a communist resistance team, based on the necessity of presenting heroically the leaders of the party in a popular Soviet novel.

The irony is that the transformations of the substance of the novel according to the party pressures of the alleged documented sources became one of the best examples of ideological fictionalization during Stalinist era. On the other hand, the Soviet critics exalted the new version of The Young Guard and appreciated the "romantic young spirit kept in the second edition, yet with a much more solid real basis, ${ }^{17 "}$ " along with the "enlarged action given by the local material, according to the dimensions about the organization of the young people in the vast picture of the fight initiated and conducted by Bolsheviks through the partisans' movement and actions of the Red Army. ${ }^{18 "}$ "The fact that all these mutations caused the modification of the structure of the main heroes and determined some serious flaws in the development of the plot was not a concern for the obedient Soviet critics.

While rewriting the novel meant bringing forth the required general image (masshtabnost') of the war, it also meant inserting some dissonant notes regarding the lyrical unity of the first edition of The Young Guard. Therefore, the lyricism was interrupted by pages of chronicle concerning the activity of the party leaders of Vorshilovgrad/Lugansk. Some of them give the impression of artificial additions (or intrusions) into the novel's organic structure, especially the praised chapter three that represented the central part of the picture preparing the evacuation, representing the "state mechanism of the war. ${ }^{19 "}$ Despite the strictly followed party direction in the second edition of Fadeyev's novel, K. Simonov wrote that "although the second edition was 'complete', it wasn't better. ${ }^{20 "}$

The first part of the novel presents various reactions of characters facing danger, be it the case of Valentina Borts' innocent autonomy, who was reading

\footnotetext{
${ }^{17}$ Rybak, 667.

18 Ibid.

19 V. G. Boborykin, Ob istorii sozdania romana A. A. Fadeyeva 'Molodaya Gvardia'. (Moscow: Prosveschenie, 1988), 213.

${ }^{20}$ K. Simonov, „Pamiati A. A. Fadeyeva” in Novyi mir, 1956, no. 6 in Bushmin, 187.
} 
Stevenson in the garden, or the case of Ulyana Gromova and Lyuba Shevtsova, who were searching for their role and meaning in the newly established order at war. The second part of Fadeyev's novel narrates the events when the young people of Krasnodon are actively involved in the resistance fight, describing the methods and the cooperation between generations. While the first part lingers on the interior states of the characters and their awakening of the patriotic conscience and responsibility, describing stages in establishing relations of collaboration between leaders and youngsters, the second part abounds in events, actions, alerted rhythm and lyrical-heroic tone with patriotic accents.

Although The Young Guard is a war novel, we consider valid the structural perspective offered by Katerina Clark on novels of the Stalinist period (especially in the case of novels of production), inspired by Vladimir Propp's narrative functions for Russian popular fairy tales. ${ }^{21}$ Clark's six large divisions, with no fixed order (unlike Propp's thirty one functions (with fixed order) may be applied on the structure of The Young Guard: prologue or separation (the heroes reach a new microcosm or the native land after an initiative journey); setting up the task (the anti-fascist fight, reaching to Bolshevik leaders, choosing the young leaders); transition or trials (of heroic-dramatic or prosaic nature); climax (with possible obstacles); initiation (the mentor and the apprentice - Lyutikov and Oleg Koshevoy) and the finale, usually a complex one, which in our case supposes the martyrdom of the young guardians.

The finale of the analysed novel is in the author's opinion ${ }^{22}$ devoid of pathos, listing all real members of the organization 'The Young Guard'. It is possible that this unconventional ending, written in sober realist style contributed to 'saving' the novel from a total rejection of critical (non-Soviet) reading.

The characters are most of the times in the middle of events: they are planning, transmitting information and fulfilling the plans, without thinking too much. As readers we are witnessing some secret meetings, a lot of running here and there to fulfil missions and imperative tasks. The impression is of a hustle (impression given also by the great number of characters), based on a hypothetical and idealised love for motherland and supported by the desire of getting involved just to act and to be part of a collective.

\section{Leonid Leonov and Cosmogonic Anti-Utopia}

Leonid Leonov's exceptional stylistic skills and his preoccupation with moral and psychological matters of people from various social backgrounds situate him as a continuator of F. M. Dostoevsky's style. His much-discussed success in the Socialist Realism context influenced the Soviet prose so that echoes of The Russian Forest may be traced in P. Proskurin's novel, social-moral issues are found in V. Rasputin's

\footnotetext{
${ }^{21}$ V. Propp, Morfologia volshebnoy skazki. Nauchnaia redaktsia, tekstologicheckii kommentarii I. V. Peshkova. (Moscow: Labirint, 2001).

22 Rybak, 668.
} 
and V. Shukshin's writings. Moreover, the psychological tension specific to Leonov's prose is evident in the Soviet literary works of the last two decades.

A kaleidoscope of the 20th century Russian scene, the novel is also a war depiction from a philosophical perspective. The larger context of previous socialpolitical mutations, ecological considerations and metaphorical connotations contribute to a better understanding of the Russian history, mentality and the forging of the Soviet identity through the becoming of a young citizen - Polya Vikhrova. The novel may be considered part of a symbolical aesthetics (along with Leonov's last novel The Pyramid) due to the same search for a connection between the human heart and the mechanisms of the universe. That is especially visible in the path of the hero Ivan Vikhrov and his daughter Polya, as well as his adopted sons Sergey and Kalinka. Their destiny is intertwined with the destiny of the Russian forest, amidst ecological and forestry usage debates.

Although not a war novel per se, The Russian Forest depicts the war events and their shaping force on the young generation of the Soviet Union. Moreover, though the author uses specific literary motives to Socialist Realism, the novel is far more complex than the average literary product of the era. Despite the audacious forestry matters presented in the novel and a myriad of ironic and transparent metaphors, Leonov's novel had its subversive and controversial character overshadowed by the political and cultural changes of the post-Stalinist period. A close reading of the novel offers enough incriminatory hints concerning the Stalinist period. Leonid Leonov's entire literary work may be considered as a virtuoso's balance between compromise and convictions. ${ }^{23}$

The theme of the Russian forest gains symbolic-philosophical connotations, representing one of the significant facets of the national history conception. The Russsian forest is the defining trait of Leonov's aesthetical and ideational searching of the '50s and '60s. ${ }^{24}$ The forest is the bearer of the secular experience of the people. Ivan Vikhrov's course about the forest presents it as the shaping factor of the nation. Furthermore, the narrator points out that there is an intrinsic link between the nature and the national character traits of the Russian people. Leonov makes an analogy between the physical state of nature and the social phenomena so that soil erosion stirs the spirit erosion, fear, sterile thinking and loss of conscience. Thus, the novel illustrates the social movement of an era, including the war between two ideologically opposed worlds (Germany and the Soviet Union), and presents allegorically realities of the 20th century.

${ }^{23}$ Boris Thomson, The Art of Compromise: The Life and Work of Leonid Leonov (Toronto: University of Toronto Press Inc., 2001), 220.

24 S. Petrov, A. Metcenko, R. Bikmuhametov, A. Abramov (eds.), Istoria russkoi sovetskoi literatury '40-'80e gody (Moscow: Prosveshchenie, 1983), 250. 
Regarding the style of The Russian Forest, we highlight the resemblance of the analepsis of Ivan's childhood as well as Polya's path through the forest in her scout mission using the skaz technique. ${ }^{25}$ The structure of the novel, alternating the rural and urban settings, reminds of the novel The Badgers, also marked by the antagonism between the two environments and their role in forming hero's character and personal convictions. The two environments stand for two different types of knowledge - the profound one, of the peasantry, whose representative is Ivan Vikhrov, and the artificial, bookish milieu, represented by Alexander Gratsiansky. This opposition dates back to the debate between the Slavophiles and Westernizers, which could be reduced to the dichotomy between the essentially Russian village and the city under the western influence. It is revealing that only a fusion between the two backgrounds may offer the society a complete and fulfilled person. That is the case of Ivan Vikhrov, despite his family issues; this is also Polya's case. The motif of scientific opposition between Vikhrov and Gratsiansky was also presented in the novel Skutarevski, but The Russian Forest provides a conflict of bigger proportions and acutely perceived by the characters during the war events.

Although considered a typical novel of the Socialist Realism by the critics of the period, the western critics took notice of the controversial aspects. It is to the point of recognizing that The Russian Forest goes beyond the limits of the canon due to its "compositional complexity and elegant form. ${ }^{26 " ~ S e v e r a l ~ R u s s i a n ~ c r i t i c s ~ h i g h l i g h t ~}$ the controversial and overturned usage of the Socialist Realism model so that the novel is a parody of the established paradigms, a social anti-utopia. ${ }^{27}$ Thus, Leonov utilizes aspects of the Soviet society and the consecrated motif of the fight of mythical dimensions between the new world and the old world in order to propose his poetic myth about the unity between man and nature. Furthermore, the dialectic scheme of narrative construction and interpretation proposed by Katerina Clark spontaneity/ consciousness - is directed toward supporting this poetic myth. Thus, perceiving the profound relationship with nature, Polya manages to find her inner balance and to find solutions to her social issues, reduced to the conflict between her father and Gratsiansky, his academic opponent.

The issue of father and child occupies a significant space in The Russian Forest, continuing the preoccupation for the gap between generations, expressed in Russian literature of the 19th century. Man's search for duty on earth receives new

\footnotetext{
${ }^{25}$ This technique is associated with Nikolai Leskov, under the influence of Aleksei Remizov and Evgeni Zamiatin.

${ }^{26}$ Elena Abrudan, Structuri mitice în proza contemporană (Cluj-Napoca: Casa Cărţii de Ştiinţă, 2003), 124.

${ }^{27}$ N. L. Leideman, Lipoveţki M. N. in A. N. Vorobiova (ed.), Sovremennaia russkaia literatura. Proza, 1970-1990-e gody: Uchebnoe posobie. (SGAKI, Samara, 2001), vol. 1, 23-35, and V. Chalmaev, Russkaia literatura XX veka. Ocherki. Portrety. Esse, Vol. 2 (Moscow: Prosveshchenie, 1994), 227-238.
} 
connotations in the context of a generation that learns about the capitalist world from their parents' memories and (censored) textbooks. Leonid Leonov explores the complex issue of historical (and family) inheritance, of taking over the duty. Just like little Ivan learns how to love the forest from the aged Kalina in childhood, his natural daughter and adopted sons learn from him the duty to protect the Russian forest for future generation. The providential meeting between Ivan and Kalinka in the forest, at the end of the novel, ${ }^{28}$ signifies the closing and opening of a new circle of passing the baton. By contrast, Alexander Gratsiansky's lack of creativity, his cynical and barren academic activity are mirrored by the fact that his only illegitimate daughter died young. Moreover, Gratsiansky's academic path remains without followers by the time he is about to be exposed as a traitor of the homeland.

The characters of the novel feel the acute need to be united with the land and the people, to feel the blend with homeland, symbolised by the vast stretch of forests of mythical origin. Considering that the forest is a Russian recurrent symbol for homeland, native land in the Russian and Soviet literature (a cliché in the fiction of the '30s and a reflection of the rise of the national feeling), Leonov reveals the theme of the struggle for rational exploitation of the forest. This theme is equivalent with the struggle for life, for homeland and for future.

The people and the forest are recurrent motives in The Russian Forest, while the unity of the people in their ardent desire to protect the homeland is constant throughout the novel. For example, when Polya is worried that she would be cast "from the bossom of the people" due to her father's unclear situation, her friend ensures her that "the people would not give up on you: you are like a grain in its palm. ${ }^{29 "}$ "Polya discovers the link between the people and the forest in her scout mission, understanding the protective role of the forest. Furthermore, Polya perceived that the Russian forest is the place where she may find "the most mysterious thought of Russia." 30 The forest is both the symbol of the people in the revolutionary period and the one to set the rhythm and the living style of the Russian peasants.

Leonov's novel focuses on the war representation moslty in the urban area, but there are also fragments that describe the war situation in the rural area. Polya's interior drama is doubled by the war drama of the entire country. The place where her interior trouble finds peace is the forest where she and her father spent their childhood. The fragments that describe that inner process combine the rational and miraculous principle, realistic and fairy tale elements. The forest is both the girl's protector, guide and supporter.

\footnotetext{
${ }^{28}$ Leonid Leonov, Pădurea rusească, transl. by I. Igiroşianu, Xenia Stroe and Teodor Solescu. (Bucharest: Cartea rusă, 1956), 772.

${ }^{29}$ Leonov, 128.

30 Ibid., 168.
} 
The compositional structure of the novel and the presence of several mentors in the heroes' life indicates a shift in the fiction of the '40s-'50s until the successive waves of the cultural Thaw. However, in Leonov's case, the presence of aspects typical for the Socialist Realism canon are not necessarily a sign of the author's obedience, but rather signs of his stylistic and ideational superiority. In this way, he builds his "cosmogonic anti-utopia. ${ }^{31 "}$

\section{Yuri Bondarev and Psychological Collision}

Yuri Bondarev is the exponent of the new wave of war writers (frontoviki or okopniki) and his prose is concerned with unveiling the truth of the trenches (okopnaja pravda). He is part of a new wave of prose writers - G. Baklanov, V. Bykov, B. Vasiliev, V. Astafiev - focused rather on the narrow view on war events from the trenches than the larger scale view on events (massshtabnost'). The novel The Hot Snow is built on the "ethical-moral collision ${ }^{32 "}$ already exposed in Bondarev's short stories. The psychological collision is organically bound to the dynamics of the action, monologue and dialogue, interior reflections, which, in turn, contribute to the formation of a unique rhythm of Bondarev's prose. ${ }^{33}$

The Hot Snow presents the familiar micro-universe of the trenches inhabited by the soldiers, commanders, nurses. The novelty is represented by an enlargement of the usual narrow perspective by introducing new characters Bessonov and Vesnin - the General and the member of the Military Council, respectively. In this way, a bigger perspective on war events is offered though in a deceiving manner. The desirable global view is not achieved, as both Bessonov and Vesnin are preoccupied with their duties and personal issues. The mastery of narrative techniques and character construction is outstanding, as the novel presents in 500 pages the events of two nights and three days on the shore of river Myshkova, not far away from Stalingrad.

The tension between the main characters is determined by the frailty of human interactions at war and by a love triangle - Zoya, her supposed husband Drozdovsky (company commander) and her secret passion Kuznetsov (division commander). Zoya's death is decisive in constructing the narrative climax and the psychological collision between the two men, as they relate and react differently to the event. Zoya would still be alive if it wasn't for Drozdovsky's negligence and selfishness. That is why not only Kuznetsov blamed the company commander for yet

\footnotetext{
${ }^{31}$ Abrudan, 126.

32 Elena Gorbunova, Yuri Bondarev. Ocherk tvorchestva (Moscow: Sovetskii pisatel', 1981), 19.

${ }^{33}$ Yuri Idashkin, Grani talanta. O tvorchestve Iuria Bondareva (Moscow: Khudozhestvennaia literatura, 1983), 12.
} 
another death caused by his inability to act properly on the battlefield and by his ambition to impress General Bessonov.

Writers of this second wave of war prose are concerned with realistic war depictions and Bondarev is no exception. The narrative voice unveils, sometimes making room for the hero's stream of consciousness, the plain fear of death. Kuznetsov's thoughts revolve around his possible, imminent death and how his corpse would look like. Obsessive thoughts about death represent the normalcy of the hero's inner life. ${ }^{34}$ Furthermore, he felt twenty years older in just one night because of the horrors he witnessed: most of his soldiers were killed in the first hours of the battle, to which Zoya's sudden and absurd death is added. The wounded soldiers complain about their fate of being wounded in the first hours of the fight, while Kuznetsov handles his war trauma poorly.

Difficult relations at war are depicted in the case of Bessonov and Vesnin. It is significant that Vesnin is appreciated only after his death ${ }^{35}$ even by the taciturn Bessonov. The General is fully absorbed by dark thoughts regarding his son lost on the battlefield to notice or care about work relations. Vesnin's sudden death is a trigger for revealing General's human nature to the awe of other commanders. For the first time Bessonov gives up his character and principles and steps on the recent place of the battlefield, searching for heroic survivors of the deadly fight. Upon handing out the war awards to Drozdovsky, Kuznetsov and several others, he is in tears, grateful for the destroyed German tanks.

Depicting such sensitive matters was unthinkable for the first ware of war writers who were concerned with the idealised heroic side of the war. Moreover, such topics are transmitted using narrative techniques that would place this prose in the category of "beyond Socialist Realism. ${ }^{36 "}$ "Bondarev's novel also highlights some ethical and moral issues that were not touched before. In this respect, the division commander, Kuznetsov, is concerned about his right to send people to battle and to give orders, knowing that any order could bring imminent death to his soldiers. On the other hand, he covers soldier Ukhanov's non-compliance with the regulations; Kuznetsov is capable of fighting to death with Drozdovsky because of his inhumane attitude to hungry and exhausted soldiers. Kuznetsov confronts Drozdovsky for the "stupid, idiotic 37 " death of young soldier Sergunenkov, who was sent to certain death in an attempt to stop an armoured car with a grenade. Furthermore, the

\footnotetext{
34 Yuri Bondarev, Zăpada fierbinte, 2 volumes, transl. by Ecaterina Antonescu (Bucharest: Editura Minerva, 1977) vol. 2, 98, 156, 208, 222, 224, 227.

${ }^{35}$ Vesnin pleads to spare the life of a strayed tank driver, while Bessonov is ready to apply the military court laws. Furthermore, it turned out that Vesnin had evidence of Bessonov's son the shameful destiny of a war prisoner - and kept his silence about this sensitive matter.

${ }^{36}$ The collocation is borrowed from the book Beyond Socialist Realism: Soviet Fiction Since Ivan Denisovich, edited by Geoffrey A. Hosking (New York: Holmes \& Meier Pub, 1979).

${ }^{37}$ Bondarev, vol. 2, 115.
} 
conflict between the two commanders reignites on virtually any matter and reaches the climax with Zoya's death.

While Kuznetsov is portrayed mainly by the stream of consciousness, Drozdovsky appears through the others' perspective - Kuznetsov, Ukhanov, Bessonov. His relationship with Zoya also sheds light on this commander's character. The physical details are provided by the narrative voice in the beginning of the novel; in key stages of the novel, his appearance is highlighted as reflections of his egotistic nature and military ambitions. Zoya's death influenced his stature and posture, reminding of a drunken man walking carelessly on the ruins of the recent battlefield.

The war is represented in a deheroicised manner, especially the military men are described as weak, hungry, exhausted and fearful human beings, or "mechanical toys. ${ }^{38 "}$ Naturalistic scenes attracted the reproach of the Soviet critics and the remarquism verdict as opposed to the heroic standards of the Socialist Realism. The described space revolves around the battlefield and the hut where soldiers gather and where the wounded would be placed.

The two raisonneurs - Kuznetsov and Bessonov - contribute to a complementary perspective on the battle near the river Myshkova. Their inner thoughts, meditations and their different access to events complete each other - the trenches in Kuznetsov's case, and surveilling the entire space of the battle, in General Bessonov's case, respectively. The blend of the two worlds separated by different military ranks coincides when the General gives in to his emotions and descends to thank personally those who defended the key position in the Battle of Stalingrad.

\section{Svetlana Alexievich and the Women's War}

Although the Soviet literature has remarkable heroines in war prose, Svetlana Alexievich is the first writer to offer a comprehensive perspective of what is means to be a girl/woman at war. The Unwomanly Face of War is a feminine perspective on war, far from the usual masculine manner of depicting the war in facts and military data. Apart from offering a different view on the Soviet canonical victorious war, Svetlana Alexievich's collection of skilfully designed oral interviews uncovers delicate issues of Soviet girls in the trenches, dugouts, in missions, doing unwomanly works.

Firstly, because of the book's controversial character in the '80s, despite literary mutations after World War II, Alexievich still had to face the Soviet censorship after self-censorship. Her different focus on women at war was regarded as an attempt to dethrone the sanctity of the Soviet womanhood and women's heroism built on Bolshevik and Stalinist cultural patterns and deeply rooted in the Soviet readers' minds (see fragments from Alexievich's conversations with the

38 Ibid., vol. 1, 51. 
censor $^{39}$ ). Tackling this sensitive subject of Soviet society may be seen as one of the last unshaken cultural constructs of the last Soviet decade despite talking about the extended shores of Socialist Realism. Secondly, notwithstanding censorship and self-censorship, The Unwomanly Face of War unveils the tensions between the culturally constructed image of the heroic, noble and victorious war during Stalinist period through literature, films, on the one hand, and the ugly, unwomanly face of war, on the other. Thirdly, the ambiguous position of Alexievich's type of writing - merging oral history with the personal diary, at the verge of fiction and document, either non-fictional novels or documentary monologues - is more revealing when it comes to realistically depicting war matters.

Soviet girls had a different status and place in the war which they had to earn and to conquer. The position of boys during the war was simpler and rapidly acquired, mirrored in Valentin Kataev's short story Son of the Regiment (1945) which depicted the specific phenomenon of regiments "adopting" orphans or lost boys. Due to the gendered perception of war, underage boys were easier accepted in the military than girls, who were associated to the rear. Although the girls benefitted from larger social and special area than in previous historical periods, ${ }^{40}$ they were still seen as unfit for combat so that military may be regarded as the most difficult social area to be conquered by Soviet women.

As in the case of Soviet boys, the girls were motivated by the same patriotic feeling inculcated through education and heroic models. But before fighting back the fascist invaders, Soviet girls had to face an "enemy from within" - the established gender roles and social-military resistance to change. The military territory was easier to conquer for the Soviet idealistically tuned female youth after heavy casualties of 1941, but girls and women were accepted only as inferior replacements of boys and men and treated subsequently. In Alexievich's book the replacement is a constant theme: “(...) there were trains passing by one after another with nothing but girls in them. (...) Now we were to replace them"; "(...) the men were taken, and we, women, replaced them. ${ }^{41 \text { " }}$

After a rough start in the trenches as soldiers and the meandering path to get to the front, girls were subjected to defeminisation or transformation into soldiers. Oral stories from Alexievich's book mention or explain this process of changing their identity from girls/women to soldiers, to a blurred identity during the war. The exterior change braids cut, dresses and shoes left behind, wearing uniforms and boots - meant that interior changes would follow (regarding the identity). The de-feminization process and assuming the soldier identity began for most girls after their first kill or after witnessing horrors done by Germans in their homeland. For most of them the new identity is

${ }^{39}$ Svetlana Alexievich, The Unwomanly Face of War. An Oral History of Women in World War II, transl. by Richard Pevear and Larissa Volokhonsky (London: Penguin Classics, 2017), xxxi, xxxv.

40 See also Alexievich, 27.

${ }^{41}$ Alexievich, 28, 29. 
equivalent to their mastering the new space and inhibiting, suppressing their specific feminine instincts (pity, compassion, love for the neighbour, respect for human life).

The acceptance of girls' presence in the trenches is possible only after defeminizing them and forcing them to embrace this non-gender identity or this gender confusion. The first woman officer in the navy concealed her gender because of the wide spread prejudice that cats and women bring bad luck at sea. Her last name, Rudenko (with no feminine ending), helped her, but her "girlish treble" gave her away and caused panic. ${ }^{42}$ Girls are aware of this transformation and sometimes want to hinder a potential total transformation of their feminine nature into "soldier": "Did we want to resemble men at the front? At first, we did, very much: we cut our hair short, we even changed our way of walking. But later, no, no way! ${ }^{43 \prime \prime}$

The gender confusion and a sort of gender fluidity at war is evident in many interviews as a confirmation of the fact that a girl cannot remain entirely a girl within the space of the war and specifically, on the frontline. Giving up long hair, the feminine outfit was only one part of this identity transformation, as many girls "adopted some male ways" along with trousers, army jacket, overcoat and boy's haircut. Adopting "male ways" also meant starting to curse "like a man" in dreadful situations. ${ }^{44}$ Living among men at the front and listening to "foul Russian curses" proved to be difficult after the war when tender words seemed "childish. ${ }^{45 "}$ A commander girl of an antiaircraft gun recognizes that despite being a tough, strong girl, in the war she was capable of going more than in peaceful life: "an unknown strength surged up from somewhere. ${ }^{46}$ " which may also explain how tiny underage girls were able to carry hundreds of wounded and dead men. Another pilot girl admits: "Like it or not something masculine appeared in your gait and your movements. ${ }^{47 \prime \prime}$

Regaining the girl identity is possible when set in a different space: at the hospital after a wound, at a dancing party, or only after the war. Regaining femininity after the war was problematic, as some interviews reveal. Some never recovered after the war trauma and wounds, others managed to return to normal civilian life. Too many preferred to keep silence regarding their involvement in the front, even though they lost their soldier status and financial support. Upon returning to normal life, within society, these girls and women would face another war after the war - fighting to be valued and reintegrated within society. Civilians tend to associate low demeanour with frontline girls and reject such brides or wives for their sons. ${ }^{48}$ These brave girls are reproached of being

\footnotetext{
42 Ibid., 202-203.

43 Ibid.,197.

44 Ibid., 324.

45 Ibid., 249.

46 Ibid., 204.

47 Ibid., 195.

48 Ibid., 237, 243.
} 
abnormal for their war experience. They are regarded as undesirable by male soldiers ${ }^{49}$ and judged harshly by women who didn't fight during the war. ${ }^{50}$

As it is clear from the quotes and tone of the book, the perspective on war events is highly demystifying and deheroicising. The content of this book had a huge effect on the war perception and the cult of victory, introduced in the Brezhnev era. Moreover, it influenced the war representation in popular culture especially the postSoviet war films. While we cannot discuss a character construction of the book, we may safely state that the hero of the book is the woman at war. In addition, the heroine is "constructed" by the war mechanisms - the transformation into a soldier after the decision to join the army, then the return to the former feminine self, back into society. The path of this collective heroine is similar but despite the heroic character, the heroine is perceived as the Other when coming back to normal life. From the Socialist Realism point of view, these are not positive heroines, but they may be regarded as such in view of their heroism and dedication to homeland. Nevertheless, their heroism and heroic deeds were devalued and relativized (or even disregarded and annulled) in that period, while the male heroism was still in high regards.

\section{Conclusive Remarks}

Our analysis of the literature about World War II reveals four main perspectives, taking into account political changes and cultural mutations. While the romantic-heroic perspective, represented by A. Fadeyev's The Young Guard, brings in the foreground an idealized depiction of the activity and death of a resistance movement, the philosophical perspective offers a cosmogonic anti-utopia in Leonov's novel. The Russian Forest is a kaleidoscope of the $20^{\text {th }}$ century Russian scene, while the war is a pretext for unveiling author's poetic myth. The slight deheroicization resides partly in the childish perspective on war events (Polya Vikhrova's view) and in the involvement of complex forestry matters linked to the Russian national character. Bondarev's psychological perspective on war consists in employing stream of consciousness, multiple views on the same character, involving other characters and revealing the demystifying "truth of the trenches." The authentic perspective points out the non-fictional literature of the Soviet Union that set out to explore the raw experience of the population, stripped of ideological and mythmaking concerns. Svetlana Alexievich's contribution with the book The Unwomanly Face of War is both necessary and remarkable, as it sabotaged one of the last Soviet unshaken cultural constructs - women's sanctity and motherly character. Alexievich's role in shaping the cultural perception of women's involvement in the war is invaluable, as is her writing method and style.

\footnotetext{
49 Ibid., 245.

50 Ibid., 248-9, 328.
} 